\title{
Nothing is forever: um ensaio sobre as artes urbanas de Miguel Januário \pm MaisMenos \pm
}

Nothing is forever: an essay on the urban arts of Miguel Januário \pm MaisMenos \pm

\author{
Paula Guerra* \\ * Universidade do Porto - Porto, Portugal \\ pguerra@letras.up.pt, mariadeguerra@gmail.com \\ https://orcid.org/0000-0003-2377-8045
}




\title{
Resumo
}

Neste artigo pretendemos analisar as intervenções artísticas politicamente engajadas de Miguel Januário, na última década, caracterizada pela premência de uma severa crise económica, financeira e social em Portugal. Ao trabalho que aqui apresentamos encontra-se uma finalidade assente num princípio heurístico primordial: o de demonstrar que a street art constitui matéria e objeto de intervenção social, demarcando um espaço próprio, definido e específico na denúncia e revelação de problemáticas sociais; multiplicando e questionando, assim, as formas e conteúdos das artes urbanas.

Palavras-chave: arte urbana; Miguel Januário; street art; artivismo.

\begin{abstract}
In this article we intend to analyze Miguel Januário's politically engaged artistic interventions, in the last decade, characterized by the seriousness of a severe economic, financial and social crisis in Portugal. The work presented here underlies a purpose based on a primordial heuristic principle: to demonstrate that street art is a matter and object of social intervention, demarcating a specific space in the denunciation and revelation of social issues; also, multiplying and questioning, thus, the forms and contents of the urban arts.
\end{abstract}

Keywords: urban art; Miguel Januário; street art; artivism. 


\section{Um prelúdio: worlds of art contemporâneos, as artes e a crise}

O texto ${ }^{1}$ que apresentamos procura analisar as intervenções artísticas politicamente engajadas de Miguel Januário, na última década em Portugal, caracterizada pela premência de uma severa crise económica, financeira e social. Ao trabalho que aqui apresentamos esteve subjacente uma finalidade assente num princípio heurístico primordial: o de demonstrar de que forma as manifestações artísticas - neste caso, em particular, a street art - constituem matéria e objeto de intervenção social, demarcando um espaço próprio, definido e específico na denúncia e revelação de problemáticas sociais (Guerra; Silva, 2014; Silva, A., 2014; Silva; Guerra, 2015). Trata-se, deste modo, de repensar as artes urbanas, nas suas formas e conteúdos, reformulando e recriando worlds of art na contemporaneidade.

Tendo por base o nosso referencial analítico, estamos perante manifestações que não procuram apenas denunciar, mas também intervir/agir, nas quais, por vezes, o incitamento remete para a ação, passando esta a ser fundamental na demarcação de um espaço próprio, produtor temático e não apenas objeto contemplativo (espelho) da realidade social. Por isso, os trabalhos de Miguel Januário, bem como os de outros artistas de street art, assumem-se como um campo produtor de denúncia e de protesto, criador de temáticas/problemáticas próprias, insurgentes na realidade ao provocar-lhe agitação e mudança pela leitura que dela faz, constituindo-se, simultaneamente, em elementos integrantes de uma identidade coletiva resultante e resultado de um processo significativo de autorreflexividade.

Posteriormente à crise internacional originada em 2008, vários países pertencentes à Zona Euro foram forçados a pedir ajuda externa. Este foi o caso, em 2011, de Portugal. Em todos estes casos, a ajuda foi fornecida pelo esforço conjunto da Comissão Europeia, do Banco Central Europeu e do Fundo Monetário Internacional, constituindo uma troika de instituições. A fim de obter a ajuda, Portugal teve de aplicar um Programa de Assistência Financeira que impôs

1 Este trabalho, como parte do projeto CANVAS - Towards Safer and Attractive Cities: Crime and Violence Prevention through Smart Planning and Artistic Resistance, foi apoiado pelo Fundo Europeu de Desenvolvimento Regional (FEDER), através do Programa Operacional Competitividade e Internacionalização COMPETE 2020 e do financiamento de projeto POCI-01-0145-FEDER-030748. 
um conjunto de medidas de natureza estrutural relacionadas com o equilíbrio das finanças públicas. A dureza e a severidade de algumas das medidas levou a que o país saísse por várias vezes à rua manifestando o seu descontentamento com as políticas levadas a cabo pelo governo. Certas questões - da soberania nacional, da pertença à Europa, da responsabilização das elites, do aumento da pauperização e da pobreza - polarizaram muitas representações e discursos expressos no espaço público. Em qualquer caso, como poderia este momento histórico delicado ser interpretado? Que lições se poderiam aprender? Como reagiram os cidadãos e suas organizações? Como foi redefinido o interesse e a visão nacional? (Silva; Guerra; Santos, 2018).

Parece-nos atinente que a sociologia pode dar alguma ajuda na resposta a estas questões. A sua contribuição mais importante reside na combinação da análise de indicadores objetivos com os sentidos da ação social, os seus símbolos, as suas crenças e as suas representações. A nossa premissa básica é que a sociologia pode beneficiar da visão artística da crise e destes últimos anos da sua vigência e vivência na sociedade portuguesa. Com efeito, a perspetiva artística da crise social é crucial porque os artistas participam nas reflexões e debates sobre estas circunstâncias históricas; porque os artistas propendem a trabalhar criativamente acerca dessas conjunturas; porque os artistas têm nas ideias, emoções e comportamentos que despertam nos atores sociais a sua matéria-prima de base para a criação artística; porque as suas obras, artefactos e performances prefiguram e configuram uma representação e um discurso sobre a realidade social (Silva; Guerra; Santos, 2018). No entanto, não nos devemos limitar a considerar as artes como mais um objeto da análise sociológica. Como Becker (2007) memora, a arte é uma forma de "dizer sobre a sociedade", como a sociologia e muitas outras ciências.

O objetivo deste texto é, portanto, o de observar como a obra de Miguel Januário refletiu os problemas sociais que afetaram a sociedade portuguesa na última década. O exercício que se procura fazer poderia, tendo em conta o material analisado, consistir unicamente na análise descritiva das ações artísticas que levou a cabo. Não obstante, a nossa análise pretende ir mais além, ao procurar demarcar uma perspetiva, ainda em construção, no que respeita à inter-relação que existe, e que se procura potenciar precisamente através da análise, entre a arte - entendida no seu campo vasto e amplo, no qual se enquadram, se não todas, variadíssimas manifestações desde o cinema, 
a literatura, a plástica/visual a street art, até à música - e as ciências sociais, nomeadamente a sociologia. Pretende-se, então, recolocar, de certo modo epistemologicamente, os posicionamentos daqueles dois domínios, numa perspetiva dialógica, onde a arte, mais do um espelho ou reflexo da realidade social, é, ela própria, criadora de ação, produtora de conhecimento ao suscitar a emergência de problemáticas que se fazem refletir na própria realidade social. O que se pretende é reforçar a necessidade de um renovado entendimento epistemológico (Guerra; Januário, 2016; Guerra; Silva, 2014; Silva; Guerra, 2015) sobre o campo das artes, enquanto produtor de conhecimento ao representar de forma própria e autónoma a realidade social, interferindo nesta, e ao condicionar e gerar análises e interpretações no seio do conhecimento instituído.

\section{Artes, desartes e recriartes: novas artes públicas urbanas}

Muito se tem falado das novas artes urbanas. Mas quais foram as mudanças das "velhas" artes públicas urbanas para as "novas"? Waclawek (2008) situa o primeiro modelo de políticas de arte pública nos anos 1960. Trata-se do paradigma art-in-public-places, que se baseava na colocação, por exemplo, de esculturas abstratas à frente de edifícios públicos ou privados. O problema é que rapidamente entramos num debate sobre o que é ou não público e arte pública. Hein (2006) sarcasticamente refere que se tivermos um tigre no celeiro, isso não o torna um animal doméstico. O mesmo pode ser dito de uma obra de arte no meio da rua. Precisamente por isso surgiu um segundo paradigma, art-in-the-public-interest, mais direcionado para programas públicos focalizados em questões sociais. Trata-se de um modelo interessado em estabelecer um diálogo democrático entre arte e a audiência. O problema, refere Waclawek (2008), é o objetivo de provocar mudanças sociais para um público entendido como homogéneo, o que, em última análise, faz com que este diálogo democrático e colaborativo acabe por manter ou reforçar as desigualdades nas relações de poder. Todavia, estes debates estão para lá dos objetivos deste artigo.

É tempo de falarmos da nova arte urbana, que está na base das novas artes públicas. Autores como Traquino (2010, 2017), Pais (2010), Eckert (2007) e Campos (2009, 2010, 2012a) falam da cidade enquanto território poliédrico de comunicação visual. E cada vez mais. Existem vários e diversos códigos 
e perímetros comunicacionais que concorrem pela nossa atenção (Arantes, 2000; Canevacci, 1993). Isso é um resultado da sociedade contemporânea estar imersa na visualidade. Jenks (1995) fala de uma sociedade ocularcêntrica. Uma sociedade em que existe uma supremacia da visão face aos restantes sentidos, muito potenciada pelos progressos tecnológicos. Numa sociedade assim, as cidades tornam-se o território para se tentar adquirir visibilidade no espaço público urbano (Brighenti, 2010). Várias entidades e grupos lutam por esta oportunidade: as empresas e a sua publicidade; o Estado, com as suas políticas culturais públicas, entre outros. O espaço público, é sempre bom recordar, não é política nem socialmente neutro. É um espaço de conflito. O poder procura gerir as várias estratégias de visibilidade (Foucault, 2013), sendo precisamente o processo de visibilidade que o impõe e sustenta; e se visibilidade for ubíqua e inquestionável, ainda melhor. Concomitantemente, o poder procura omitir tudo o que coloca em causa a sua narrativa. Todavia, existem diversas vontades que se querem afirmar na esfera pública, uma vez que nem todos têm a capacidade de marcar o seu poder através de uma visibilidade urbana. Mas é na cidade onde se dá este combate pela visibilidade (Brighenti, 2010; Costa; Lopes, 2015a; Scott, 2014; Traquino, 2010). Quando falamos destas lutas, não podemos esquecer o papel das subculturas e as suas atividades para se fazerem ver e ouvir. Guerra (2018) explicou detalhadamente as estratégias de visibilidade dos punks portugueses no espaço urbano. Campos (2010, 2012b), Cerejo (2007) e Felonneau e Busquets (2001), por seu lado, abordam as gramáticas subversivas acionadas pelo graffiti e street art para a apropriação do espaço urbano. Goldstein e Perrota (1992), consideram o graffiti uma forma de reivindicar o espaço urbano, uma maneira de colocar em causa o controlo do espaço urbano por parte do Estado e grandes empresas.

Abordemos velozmente a história do graffiti, desde os primórdios na década de 1970 nos Estados Unidos até à atualidade, em que se verifica o resultado de uma legitimação desta prática artística. Surgindo na década de 1970 nos Estados Unidos, o graffiti foi rapidamente associado com vandalismo (Gastman; Neelon, 2011; Waclawek, 2011). E, como todo o vandalismo, tinha de ser erradicado - estratégia que, durante muitos anos, foi adotada pelas entidades públicas e forças de segurança (Ferrell, 1996), e que viria a fracassar. A popularidade do graffiti espalhou-se um pouco por todo o mundo. Mas ao mesmo tempo que se espalhava, também se refinava, deixando de ser simples tags e tornando-se em murais mais detalhados e complexos. Os primeiros debates 
sobre se isto seria ou não arte surgiam e, na verdade, ainda hoje se mantêm (Snyder, 2011), não obstante, ter-se começado a ver graffiters a serem convidados a expor as suas obras em galerias e museus. Tal seria o primeiro passo para uma (re)legitimação artística (Waclawek, 2011).

O graffiti português surge apenas nas décadas de 1980 e 1990, muito associado à cultura hip-hop que também então surgia (Fradique, 2003; Moore; Cruz, 2008). O primeiro grupo de graffiti em Portugal formou-se em Carcavelos, sob os auspícios de KAZAR, um writer francês. Por seu turno, em Almada, especialmente devido ao facto de aí existir uma forte cena hip-hop, surgiu a crew PRM, uma das principais responsáveis pela divulgação desta forma artística pelo país. E da imanente associação graffiti/vandalismo que também existia, vai-se mudando para uma reação e consequente atuação mais tolerantes, nomeadamente das autoridades, quando comparadas com as de outros países. Ora, esta leniência teve um efeito positivo na cena graffiter: permitiu o despoletar de um conjunto de jovens artistas, o que explica atualmente que um pequeno país como Portugal tenha vários graffiters reconhecidos internacionalmente (Campos, 2017). A partir de 2000, constata-se o pleno reconhecimento, privado e público, do graffiti como prática artística (Costa; Lopes, 2015b, 2017), em grande, devido às estratégias de divulgação dos próprios artistas. Membros da crew LEG e outros writers organizaram as primeiras exposições de arte urbana em Portugal. Uma das primeiras, com o nome 1/4 de Graf, foi realizada em 2003, com o apoio da Câmara Municipal do Seixal. Em 2005, o coletivo VSP organizou a primeira grande exposição de graffiti feita em Portugal, no Espaço Interpress, com o propósito de dar a conhecer uma perspetiva mais artística e estética do graffiti (Eugénio, 2013, p. 27-29; Moore; Cruz, 2008, p. 74-80).

Nesta evolução e reconhecimento, não será de escamotear o papel das autarquias, especialmente as ações da Câmara Municipal de Lisboa (CML), que viu nesta nova arte urbana uma forma de revitalizar o espaço público e de aproveitar uma aura de cosmopolitismo que acarreta. Mas vejamos alguns exemplos de práticas da CML: em 2008, na sequência de um processo de limpeza de fachadas no Bairro Alto, criou a Galeria de Arte Urbana (GAU), que tem como missão a promoção do graffiti e da street art em Lisboa num contexto autorizado. Apesar de um contexto inicial de desconfianças mútuas, a decisão deu os seus frutos e Lisboa se tornou uma paragem obrigatória nos roteiros de arte urbana (Campos, 2017). O sucesso desta estratégia teve um efeito 
dominó e, desta forma, mais autarquias portuguesas procuraram utilizar a arte urbana como forma de resolver vários problemas. Por outro lado, um conjunto de instituições artísticas portuguesas começaram a reconhecer a relevância destas práticas artísticas. O ESTAU, o Festival Estarreja Arte Urbana, que torna a cidade um museu de arte urbana a céu aberto; o Festival Iminente, organizado pelo artista português Vhils e pela galeria Underdogs; as exposições de street art no Centro Cultural de Belém, no Museu da Eletricidade, da Fundação EDP, que recebeu a exposição Dissecação de Vhils, por exemplo. Mais relevante é o futuro Museu de Arte Urbana e Contemporânea de Cascais, um museu para a arte urbana geral e para a coleção de Vhils em particular.

De todos os quadrantes subsiste uma crescente preocupação com a arte urbana. Da parte das autarquias vemos a criação de roteiros de arte urbana, como mais uma forma de distinção na constante luta internacional das cidades para captar a atenção dos turistas; dos museus e galerias, assistimos a uma crescente atenção a esta (até então) efémera e desvalorizada forma de expressão artística; dos media, que tornaram certos graffiters verdadeiras celebridades e que não se cansam de procurar o próximo grande nome da arte urbana nacional; da academia, com um crescente número de trabalhos a abordar esta realidade. Ou seja, o graffiti e a street art passaram a ser reconhecidos como fazendo parte legítima do mundo da arte.

Esta legitimação não passou ao lado das empresas. Tornou-se usual a utilização destas artes urbanas em campanhas de publicidade (Botterill, 2007). Veja-se o caso da recente campanha publicitária da nova cerveja da Super Bock: a Coruja. Uma campanha que recorreu ao adbusting, isto é, uma prática artística de deturpação de publicidade. Uma prática transgressora por excelência. A verdade é que as artes urbanas têm sido cooptadas por um crescente número de empresas para gerar atenção e publicidade (Paulos, 2018).

Voltando ao graffiti. Existem dois modelos de graffiti na aceção de Garí (1995). Apesar de ambos assentarem na transgressão, existem diferenças. O primeiro modelo, europeu, encontra-se muito ligado ao pós-Maio de 1968; trata-se dos famosos graffiti (e cartazes) mordazes, satíricos, nonsense que todos nos lembramos quando pensamos nesse mês de efervescência revolucionária. Um modelo, portanto, que assenta numa base filosófica. O segundo modelo, americano, ancora-se, acima de tudo, na cultura de massas e na pop, assentando numa base imagética. 
Apesar de os dois modelos abordados não esgotarem a diversidade artísticas que hoje encontramos nas paredes das cidades, e de não serem modelos estanques, a verdade é que se trata de um bom ponto de partida para a análise que procuramos efetuar. A questão da transgressão, como já mencionado, é essencial. E aqui encontra-se uma outra divisão que é necessário realçar: a vertente ilegal e legal do graffiti (Diógenes, 2015, 2017). A primeira, que é denominada como bombing, é uma clara violação das normas, como o grafitar em locais proibidos; a segunda vertente encontra-se mais relacionada com a mudança que aconteceu nos últimos anos no graffiti, isto é, o seu processo de legitimação artística que permitiu que vários graffiters prosseguissem uma carreira. Esta vertente legal encontra-se muito associada a pedidos institucionais; Campos (2009, 2017), no que respeita à arte urbana, assinala uma ambivalência e vastidão que permite englobar vários modelos: de transgressão pura até projetos institucionais. Retendo a dimensão da transgressão, adiantamos que esta pode assumir várias formas: desde o uso de linguagem obscena, passando por mensagens amorosas ou simples afirmações como "X esteve aqui!", ou, ainda, assumindo um propósito de transgressão qualitativamente diferente, especialmente quando implica uma imprevista perturbação do espaço público e da reação das pessoas face ao mesmo. No fundo, quando as expetativas coletivas relativas ao espaço público são colocadas em causa. É exatamente por este motivo que consideramos o trabalho de Miguel Januário tão relevante, como mostraremos mais tarde.

Acima mencionamos, em breviário, o processo de legitimação da arte urbana e do graffiti. Neste momento vamos analisar um pouco mais detalhadamente este processo. Não é possível falar da sua relevância sem atendermos ao poder mediático da cidade de Nova Iorque. Publicidade, filmes, séries, etc., tudo isto serviu para divulgar uma estética do graffiti nova-iorquino e que rapidamente se espalhou pelo mundo, a par de um novo género musical, o hip-hop. E muito rapidamente as primeiras exposições de graffiti tiveram lugar na Europa em espaços prestigiosos. Veja-se as exposições em 1991 no Musée National des Monuments Français e em 1992 no Centre Georges Pompidou. Sequeira (2015, p. 51) não tem dúvidas ao afirmar que estas exposições marcam o início da legitimação do graffiti em instituições artísticas consagradas.

Não se pense, todavia, que o sucesso foi instantâneo. Os resultados destas exposições deixaram a desejar. Sequeira (2015) levanta algumas possibilidades para esta falha de comunicação inicial. Primeiro, o público apercebeu-se da 
artificialidade da transposição de um fenómeno artístico urbano para as paredes de museus. Houve um choque nas expetativas: num momento via os graffiti em carruagens de comboios e no outro no Musée National des Monuments Français, completamente fora do seu contexto original. Uma segunda possibilidade levantada poderá ter sido a procura, por parte dos públicos, de uma mensagem política nesta arte urbana, preocupação que não existia nos writers de então; estamos a considerar writers que se inseriam no modelo americano postulado por Garí (1995). Uma terceira e última possibilidade terá sido o próprio comportamento dos writers, que faziam parte de um grupo social muito fechado. Como Sequeira (2015, p. 51) constata, existiu um choque entre o público "que tentava enquadrar o graffiti na sucessão de eventos da história da arte contemporânea" e os writers, "cujos referentes não eram os da história da arte mas os do contexto socioeconómico de onde provinham e do imaginário da cultura popular".

Com maiores ou menores dificuldades, a legitimação do graffiti e street art não abrandou. Esse processo de legitimação pode ser apreendido nos esforços que o mundo da arte fez para capturar este novo tipo de arte. Isto é, não se apoiaram no léxico utilizado na cena graffiti, inventando um novo. Stahl (2009) enumera post-graffiti, high urban folk art, subway art, spray can art e street art. O propósito, na aceção deste autor, era claro: omitir a primeira fase do graffiti baseado em práticas ilegais. Se a exposição no Musée National des Monuments Français em 1991 pode ser vista como o tirocínio do processo de legitimação, o momento em que este processo se completou ocorreu em 2008, com a exposição exclusivamente dedicada à street art na Tate Modern. Desde então a popularização não deixou de aumentar. Levando em consideração o espaço consagrado como a Tate Modern, podemos afirmar que foi o movimento em que a canonização se completou, com tudo o que isso implica (Matos, 2015; Merrill, 2015).

\section{Artes, cidadania, ativismos e artivismos}

No início do século XXI surgiu uma nova linguagem, que misturava arte e ativismo social: o artivismo. Tem como suas influências uma mistura entre graffiti, arte urbana, do-it-yourself punk (Guerra, 2018), situacionismo e o seu palco 
preferido: o espaço urbano. Surgiu inicialmente em pequenos grupos artísticos e académicos nos Estados Unidos e rapidamente foi-se espalhando pelo mundo. Como acima mencionamos, a cidade, enquanto espaço de lutas por visibilidade, passou ainda mais a ser o espaço predileto para uma atividade artística com propósitos sociais ou reivindicativos (Ardenne, 2008).

Uma possível definição de artivismo é avançada por Raposo (2015, p. 3):

A sua natureza estética e simbólica amplifica, sensibiliza, reflete e interroga temas e situações num dado contexto histórico e social, visando a mudança ou a resistência. Artivismo consolida-se assim como causa e reivindicação social e simultaneamente como ruptura artística - nomeadamente, pela proposição de cenários, paisagens e ecologias alternativas de fruição, de participação e de criação artística.

Este neologismo apela à antiga ligação entre arte e política. A arte, neste sentido, tem um papel crucial na resistência e subversão ao status quo. Propõe uma dupla rutura: com a visão da arte pela arte, afastada da realidade social, e com o estado das coisas. $\mathrm{E}$ tudo isto através de um conjunto de intervenções estéticas, poéticas, performativas, etc. Para Raposo (2015) trata-se de uma nova vaga de luta pelo direito à cidade; uma nova força para a luta pelo poder da visibilidade nas cidades.

Num contexto de artificação da esfera pública (Kellenberger, 2000) e politização artística, Gonçalves (2012) refere que desde a década de 1990, um pouco por todo o mundo, assistimos à colaboração entre artistas e grupos/movimentos sociais, que se organizam para lutar e criticar várias questões sociopolíticas. Uma questão interessante é o afastamento das usuais formas de ação política. As práticas levadas a cabo são mais direcionadas para a noção do político e não da política. E a lógica de atuação é semelhante àquela encontrada nos novos movimentos sociais: pouca estruturação, relações em rede, ação direta, adesões por afinidades e não por partilha ideológica (Gonçalves, 2012). Isso remete, também, para um quadro de crise da política institucional.

Podemos então introduzir os trabalhos de Maffesoli e de Certeau. Maffesoli (2004, 2007) postula dois conceitos relevantes para a compressões do fenómeno do artivismo: o de "centralidade subterrânea", que serve como eixo que preside os movimentos da vida social de atores sociais e que não se revê, nem é valorizado, pela lógica dominante. O que não impede de ser a base de modos 
e estilos de vida frutuosos. Por outro lado, temos o conceito de "poder instituinte" que é diametralmente oposto ao "poder instituído" constituindo-se como uma alternativa. E é exatamente isso que o artivismo propõe ser. Certeau (1994), por sua vez, fala de um vasto processo de politização das práticas quotidianas nas sociedades contemporâneas. Mas o que nos interessa para este artigo é que uma dessas práticas passaria por uma "estética da apropriação". No fundo, uma espécie de bricolage, em que os atores tentariam subverter as representações sociais e lógicas culturais e, com isso, provocar uma reflexão e posicionamento crítico.

Torna-se quase impossível pensar o artivismo fora da cidade, já que é nesta que surgem os novos movimentos sociais envolvidos em lutas anticapitalistas. E é aqui que medra o artivismo, o qual ganhou ainda mais força após a crise económica de 2008. Apesar de para muitos a arte e a política se situarem em esferas afastadas entre si, a verdade é que existe uma já longa tradição contracultural face ao status quo. Mas ainda persiste a ideia que a arte não deve ser panfletária, que não deve cair na simples propaganda ideológica. No fundo, como Léger (2012) constata, a crítica apenas pode ir até um certo ponto: criticar, muito bem, mas que não se ameace o status quo. Por outro lado, existe a desvalorização da arte em ações políticas. Quer dizer, a arte desvalorizaria a credibilidade da ação política. Se de um lado existe uma arte pela arte, nesta perspetiva a crítica é de uma política pela política. A ideia é que a arte, e especialmente o artivismo, introduziriam uma folclorização espúria nos debates políticos (Raposo, 2015).

O artivismo põe todas estas críticas e dúvidas de lado. Propõe a recuperação da atividade artística como forma de intervenção social. Uma intervenção que balanceia entre três características: visibilidade, durabilidade e risco. Aladro-Vico, Jivkova-Semova e Bailey (2018) consideram que o artivismo não é apenas uma arte oposicional. A sua grande força é a capacidade de realçar as injustiças e desigualdades sociais através de um conjunto de linguagens, imagens, metáforas, etc., alternativas. À semelhança do processo de bricolage acionado pelos punks na década de 1970 (Hebdige, 1979), o artivismo origina uma reconceptualização semântica de objetos, espaços e até partes inteiras de cidades. Procura gerar acontecimentos que rompam a estrutura da comunicação convencional (Aladro-Vico, Jivkova-Semova; Bailey, 2018, p. 12).

Isso foi visível em Portugal nos anos da crise económica. A crítica social e o ativismo política foram componentes chave de inúmeros trabalhos e performances artísticas. $\mathrm{O}$ artivismo nesses anos (e ainda o é) foi entendido como 
um instrumento crucial e indispensável para a mobilização contra a hegemonia ideológica neoliberal e o poder político da troika e do governo português. Ações artistísticas que não se cingiram unicamente a artistas e organizações marginais, mas que também partiram de instituições centrais do campo cultural português. Tudo isto serviu para uma reconsideração e revisão da dimensão política e responsabilidade social dos artistas (Mourão, 2013, 2015; Silva; Guerra; Santos, 2018).

\section{\pm MaisMenos \pm : nothing is forever}

Como referimos na secção anterior, as ações artivistas em Portugal têm sido vastas e heterogéneas. Constituem um manancial importante para analisar os problemas sociais que afetaram a sociedade portuguesa. É por isso que decidimos abordar a obra de Miguel Januário, um artista bastante ativo durante os anos da crise (mas não só) e que desenvolveu uma obra que repensa criticamente as noções de identidade nacional, de democracia e do sistema capitalista.

Miguel Januário nasceu no Porto em 1981 . O seu primeiro contacto, ainda em criança, com o graffiti foi através do filme Wild style, de 1983 e um dos primeiros a retratar a cultura hip-hop e graffiti nova-iorquina. E a curiosidade ficou. Contudo, foi enquanto estudava artes gráficas na Escola de Ensino Artístico de Soares dos Reis que este contacto se tornou mais sustentado e foi o despertar para a sua trajetória na cena graffiti, na qual se manteve durante vários anos com o nome de Caos (Marinho; Cruz, [s.d.]). Todavia, Miguel Januário é acima de tudo associado ao projeto \pm MaisMenos,$\pm{ }^{2}$ que o tornou uma referência nacional e internacional no mundo da street art. Inicia o curso de design de comunicação na Faculdade de Belas Artes da Universidade do Porto em 1999 e, a partir desse ano, começa a desenvolver intervenções de graffiti na cidade do Porto e, em paralelo, trabalhos encomendados. Estabeleceu-se também como freelancer no espaço cultural Maus Hábitos, ${ }^{3}$ no Porto, onde criou o seu primeiro estúdio. Em 2005, quando cursava o último ano de design de comunicação, teve

2 A homepage do projeto está disponível em: http://maismenos.net/.

3 Espaço de intervenção cultural fundado em 2001 e situado na Rua Passos Manuel, na cidade do Porto. Homepage disponível em: https://www.maushabitos.com/. 
de desenvolver um projeto final de curso. Aqui sentiu a necessidade de ligar o que fazia na rua, o que tinha aprendido no seu background ligado ao graffiti, e o que tinha aprendido na faculdade. A este desejo de querer fazer algo com outro impacto acrescentava-se uma certa fadiga com o graffiti convencional. O seu propósito era criar uma marca antimarcas. E o \pm MaisMenos \pm é a representação do binarismo da sociedade contemporânea e do sistema capitalista, onde uns têm mais e outros menos (Januário, 2014, 2015). Assim, no ano de 2005, passou várias noites a escrever \pm MaisMenos \pm em várias zonas do Porto. O seu objetivo era ser tão viral que acabasse por se tornar uma "marca" no imaginário das pessoas. Como diz, foi "uma grande invasão no Porto, que durou dois meses" (Silva, H., 2005). De realçar que nesta primeira fase manteve o seu anonimato.

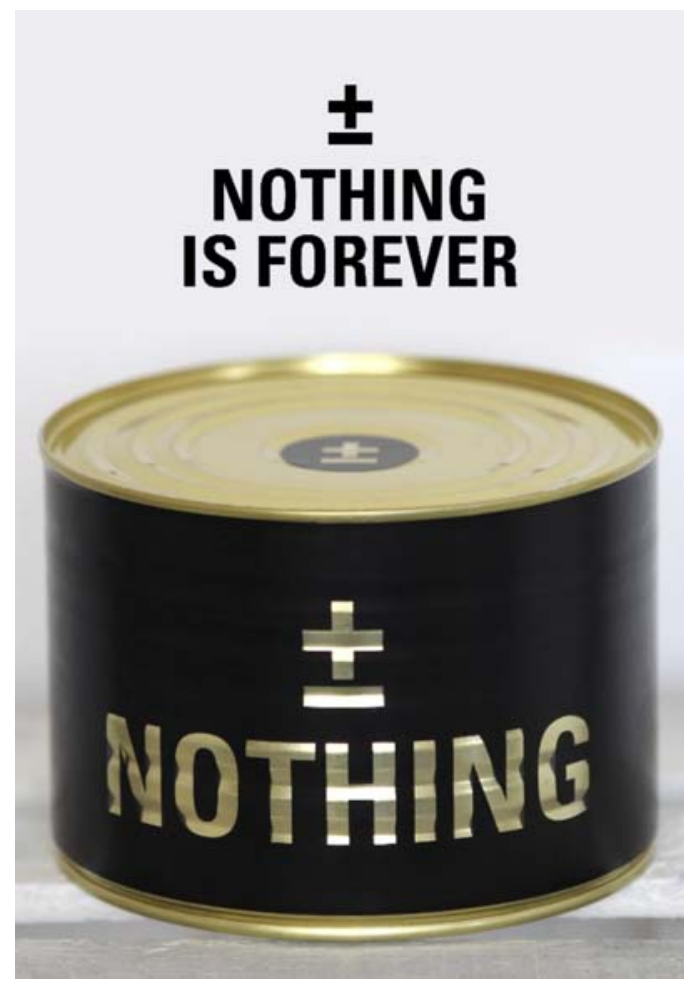

Figura 1. Nothing, a ideia subjacente ao projeto \pm MaisMenos, \pm 2013 (imagem cedida por Miguel Januário). 
É interessante assentar o enfoque na sua posição ambígua. Miguel Januário estava prestes a se tornar designer. $\mathrm{O} \pm$ MaisMenos \pm é também uma forma de se criticar a si mesmo. Ou pelo menos o que viria a ser: um designer. Via o design como uma ferramenta que cria ilusões e mentiras para o mercado; um maquilhador do capitalismo, o que faz o mercado sobreviver (Januário, 2014, 2015; Marques, 2011). Se compararmos isto com a sua posição crítica face ao capitalismo, era de esperar um choque entre a sua ideologia e o seu trabalho. O caminho para sair deste imbróglio foi criar o \pm MaisMenos \pm com o objetivo de romper e adulterar o sistema de informação que faz o mercado sobreviver.

O seu corpus artístico-criativo foram mais as frases e não tanto os desenhos e pinturas. Este estilo remete, primeiro, para uma negação que então sentia relativamente ao graffiti. Queria escapar à estética do graffiti, algo mais interventivo. Este estilo cru e direto e incisivo foi uma opção em contraponto ao estilo do graffiti. Num meio em que a intervenção é mais complexa, colorida, figurativa, etc., o seu estilo distingue-se pela crueza e simplicidade (Pinetree, 2017; Ramalho, 2014). E sempre com uma elevada dose de ambiguidade, o que é visível nas frases. Para dar espaço ao pensamento. Ora, o que temos aqui é uma das características que veremos em todos os trabalhos de Miguel Januário: criticar o sistema usando as suas próprias armas. Neste caso, como pretendia criticar o design e os meios de comunicação, utilizou as suas referências (Januário, 2014, 2015).

Peculiares são as dúvidas que inicialmente $0 \pm$ MaisMenos \pm provocou. Uma reportagem no Jornal de Notícias (Silva, H., 2005) diz claramente o que ia na cabeça das pessoas: "Não pertence a uma associação nazi, nem a uma seita religiosa, nem a grupo anarca. Não é ladrão nem chinês." A simplicidade estética da sua obra permitia uma ambiguidade que alargava o seu âmbito inicial: esta diversidade de opiniões, desde nazis até anarcas, metendo chineses pelo meio, é a prova que o seu projeto era entendido como uma obra aberta (Eco, 2009). Isto é, uma obra em que os intérpretes, neste caso toda a população de uma cidade, a interpretavam livremente sem terem em conta qualquer contexto ou ajuda. Uma tela em branco. O que faz com que cada pessoa lhe associe os seus próprios desejos ou receios. Permite também auscultar as preocupações sub-reptícias das pessoas (Januário, 2014). E isto será, como veremos, uma constante na sua obra.

Depois do curso, começou a escrever frases como "É uma casa portuguesa sem certeza" "Pague leve levemente", etc., sempre no anonimato. É interessante a forma como subverte expressões conhecidas, numa espécie de estilo sara- 
maguiano de subverter expressões conhecidas e provérbios. ${ }^{4}$ Nestes streetments é claro o seu posicionamento político. Foi também a ocasião de demonstrar a sua posição crítica e interventiva do \pm MaisMenos \pm . O salto quantitativo e qualitativo ocorreu quando o projeto \pm MaisMenos \pm se juntou à manifestação da Geração à Rasca, ${ }^{5}$ de 12 de março de 2011 . 0 cruzamento entre arte e movimentos sociais que acima mencionamos. Nesta manifestação chamou a atenção uma bandeira portuguesa sui generis.

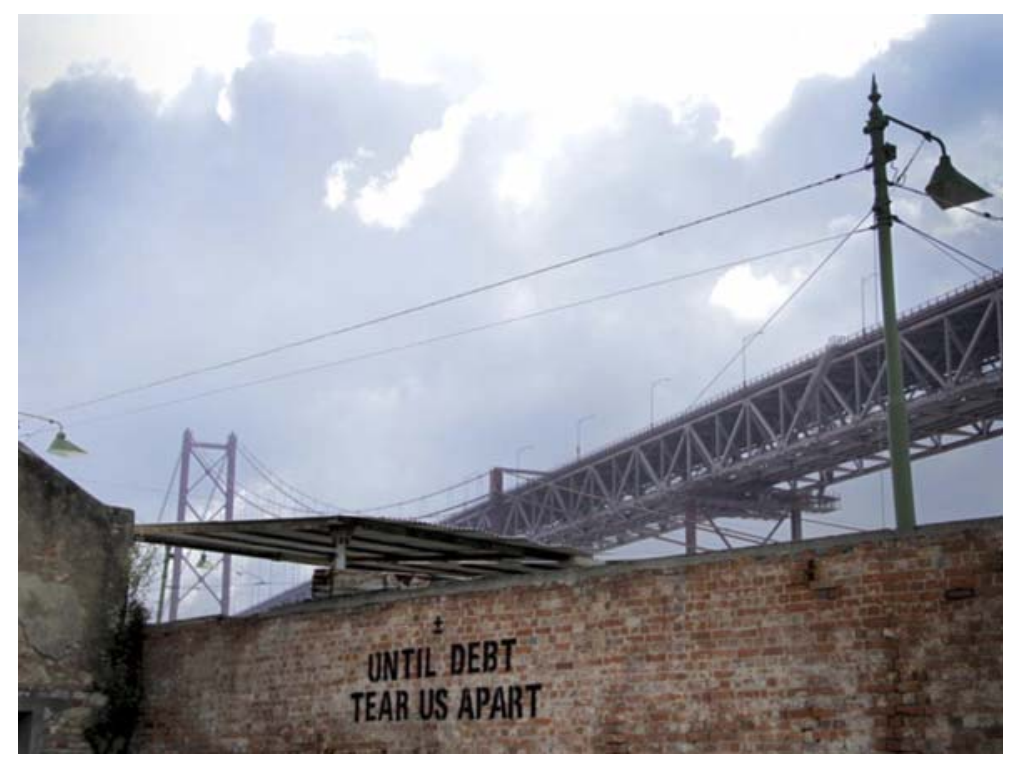

Figura 2. Exemplo de um streetment (imagem cedida por Miguel Januário).

Uma bandeira em que substituiu a esfera armilar da bandeira portuguesa pelo símbolo \pm MaisMenos \pm , para representar o estado em que se encontrava o país. Sempre a oposição binária: para uns o país está melhor, para a grande maioria está bem pior. Mas aqui começou uma nova fase da obra de Miguel Januário:

4 Disponível em: http://maismenos.net/streetments.php.

5 Um chapéu de chuva utilizado para descrever um conjunto de manifestações e protestos ocorridos em Portugal no dia 12 de março de 2011 contra a crise económica. 
a reapropriação de símbolos do país. O retrabalhar dos símbolos do país será uma constante. ${ }^{6}$ Um discutir Portugal (Januário, 2015). Esta visão de morte/renascimento do país será abordada de forma mais detalha no projeto \pm PORTUGAL 1143-2012 \pm , que analisaremos mais à frente.

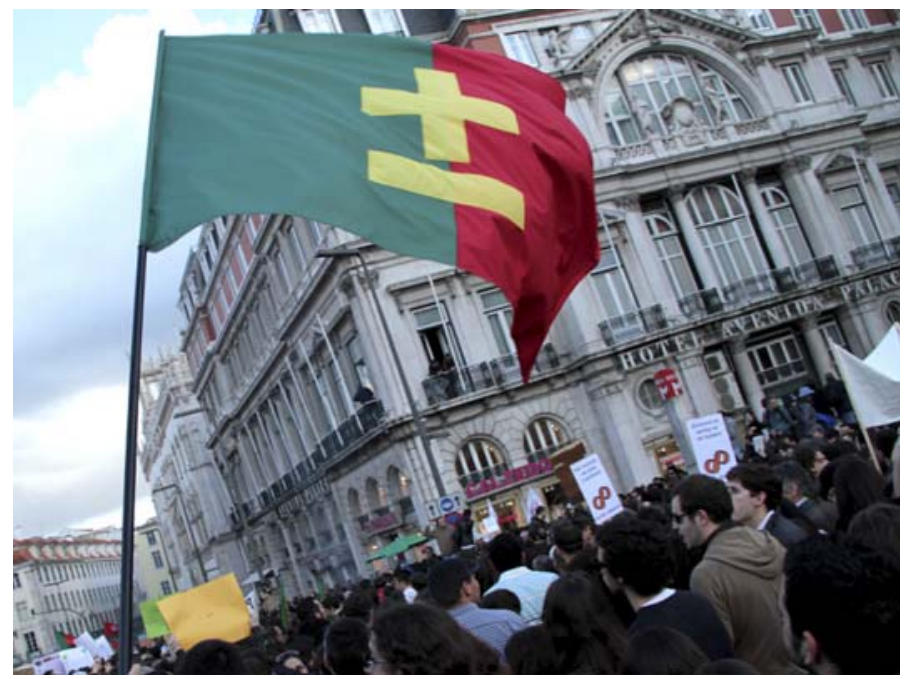

Figura 3. Bandeira nacional criada por Miguel Januário, 2011 (imagem cedida por Miguel Januário).

Um segundo momento de "explosão" do \pm MaisMenos \pm na opinião pública foi a sua performance intitulada Ego sum panis vivus. ${ }^{7}$ Esta performance tem um contexto muito específico. Numa altura em que se começava a sentir os efeitos da crise económica, o governo ponderou um corte no IVA do golfe. O problema é que simultaneamente pretendia aumentar a taxação em vários bens essenciais, nomeadamente o pão. Foi o despoletar para uma performance artivista.

Com uma música religiosa como pano de fundo, o vídeo começa com Miguel Januário a dirigir-se lentamente para as escadarias da Assembleia da

6 Disponível em: http://maismenos.net/streetments/portucale.php.

7 Disponível em: http://maismenos.net/adverthazard/egosum.php. 
República com uma indumentária de golfista e com o respetivo saco de golfe. Isto sob o olhar impávido da guarda de honra, que protocolarmente nada pode fazer, apenas chamar a segurança. Olha em volta, pousa o saco e dá uma tacada de golfe na direção da Assembleia da República. Em seguida, retira-se calmamente sob o olhar de alguns transeuntes curiosos com o que estaria a acontecer. É de salientar que em vez de uma bola de golfe, tinha um pão. Isto servia para colocar em ridículo as prioridades da classe política portuguesa e de como as preocupações económicas dominam as preocupações políticas. De igual modo, isto aplica-se ao mais e menos: o mais era o luxo, o golfe; o menos eram os bens de primeira necessidade. O luxo era alvo de preocupações; os bens de necessidade sofriam uma taxação adicional. Foi um vídeo que, como hoje tanto se diz, se tornou viral nas redes sociais. Mas não só. Os media generalistas também não deixam de assinalar a performance. Não tivesse esta acontecido a 23 março de 2011, dia de demissão do primeiro-ministro José Sócrates.

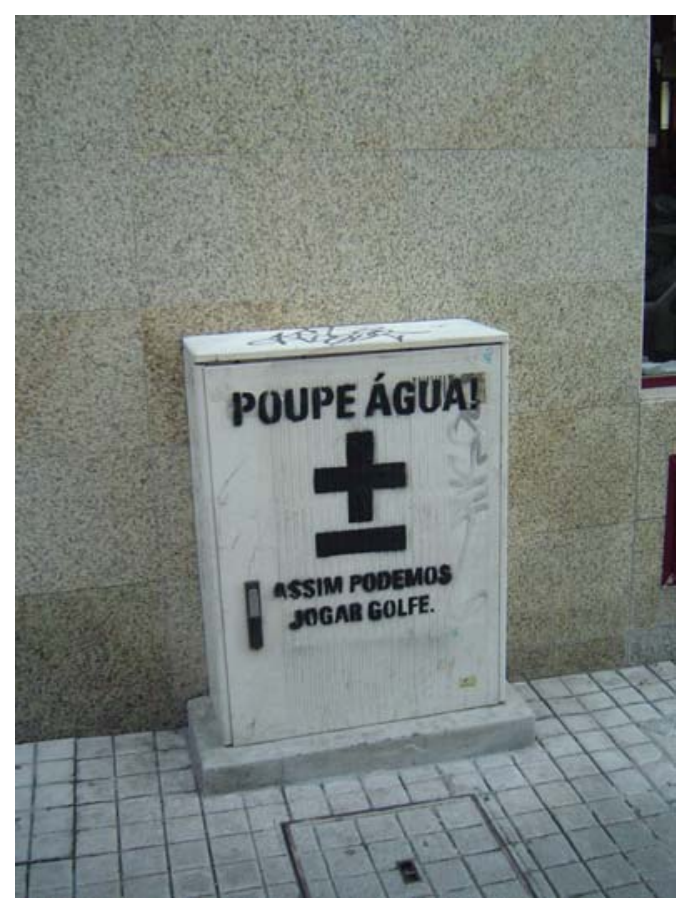

Figura 4. Um exemplo da série Portucale (imagem cedida por Miguel Januário). 
Mas esta performance é sintomática de uma preocupação que vai para além do trabalho de Miguel Januário. Isto é, o descrédito da política representativa na conceção destes artistas. A ideia que o sistema político é desmobilizador, elitista e afastado das preocupações gerais. Como acima mencionamos, é que ao mesmo tempo que encontramos no projeto \pm MaisMenos \pm uma politização da ação artística, também encontramos uma rejeição das usuais formas de ação política. É o enfoque na noção do político e não da política. A política é aqui entendida como um epifenómeno do sistema económico com o seu próprio sistema de comunicação baseado em desmobilizar e alienar as pessoas. Desta forma, contra essa propaganda, envolveu-se, com mais dois artistas, em um Ministério da Contrapropaganda. No primeiro dia deste "ministério", não se contiveram em criticar a panaceia que o governo usava para tudo e mais alguma coisa: o empreendedorismo. Com o lema "Um dia, tanto 'empreeendedorismo' havia de voltar para vos morder no cu", ${ }^{8}$ poucas dúvidas deixava sobre as suas motivações.

Por outro lado, uma das maiores preocupações de Miguel Januário é a cooptação da street art. É por isso que a sua estratégia passa por aproveitar a ambiguidade nas relações institucionais que se vão gizando. Atualmente, e se calhar desde sempre, é impossível trabalhar sem relações institucionais. Estas existem sempre, seja com estúdios, instituições públicas. O que não admite e se recusa liminarmente é um diálogo com marcas e grandes corporações, pois isso levaria a uma domesticação da street art. E é isso que se vê hoje em dia. Num momento a intervenção deixa de ser subversiva e passa a fazer parte do mainstream (Pinetree, 2017). Veja-se o que fez com a exposição Sell out ${ }^{9} \mathrm{em} 2013$. Aproveitando a sua canonização na cena artística, é convidado pela galeria Underdogs ${ }^{10}$ e pela CML, que fornecia uma parede para ele pintar. Envia a sua ideia inicial, que era uma parede com a expressão "Sell Out", mas na altura escreve "Vende-se Portugal". Uma forma de se aproveitar subversivamente da institucionalização do seu projeto, de tirar partido das instituições (Januário, 2015).

8 Disponível em: https://ministeriodacontrapropaganda.wordpress.com/

9 Disponível em: http://www.under-dogs.net/exhibitions/maismenos-solo-show/.

10 Surgida em 2010, em Lisboa, é uma galeria que é simultaneamente quer um espaço para exposições quer como lugar para residências artísticas. 


\section{\pm PORTUGAL 1143-2012 \pm}

Em 2012, Guimarães, o berço de Portugal, foi a cidade escolhida para ser a Capital Europeia da Cultura. Uma iniciativa europeia que todos os anos promove uma cidade que pode mostrar a sua cultura e modo de vida a toda a Europa. Em 1994 tinha sido Lisboa e em 2001 a cidade do Porto. Um acontecimento muito aguardado pela cidade de Guimarães e zonas circundantes. Não é usual que num país macrocéfalo como Portugal iniciativas deste género aconteçam numa pequena cidade do norte do país.

Durante este ano, como seria de esperar, existiu um programa oficial cultural preparado ao detalhe. Miguel Januário não esteve aí presente. Esteve, isso sim, presente, num programa paralelo, o One Off, levado a cabo pela associação Saco Azul, ${ }_{11}^{11}$ organização responsável pelo espaço Maus Hábitos e à qual Miguel Januário pertence. Foi neste programa paralelo ao oficial em que foi convidado como artista residente (Pinetree, 2017). Desenvolveu, neste espaço de tempo, o trabalho artístico \pm PORTUGAL 1143-2012 $\pm{ }^{12}$ dividido em quatro performances artísticas. Performances que deixaram a sua marca, pois, aproveitando a simbologia da cidade de Guimarães, todas remeteram para a história de Portugal e a sua decadência atual. Uma forma de ilustrar o que se passava no país. Como referido, foram quatro as performances: Aviso, Traição, Repressão e Morte. Ficaram duas por fazer: Ressurreição e Reconquista (Mais..., 2013; Pinetree, 2017).

Na cidade batizada como o berço da nação e mais associada à figura de D. Afonso Henriques, o primeiro rei português. É aqui que se situa o famoso Castelo de Guimarães, classificado como monumento nacional, e que tanto simbolismo acarreta. Ao ponto de ter ficado em primeiro lugar, na campanha pública Sete Maravilhas de Portugal. Enfim, tratava-se de uma oportunidade demasiado boa para escapar: fazer um contraste entre a história e a atualidade.

A primeira performance, Aviso, ${ }^{13}$ começa com os primeiros acordes em piano d'A Portuguesa e, quando começa a imagem, deparamo-nos com um espaço industrial abandonado. $\mathrm{O}$ mais estranho é quando se começa a cantar o hino.

11 Trata-se de uma associação cultural composta por um núcleo de artistas e que acaba por ser o motor do espaço Maus Hábitos. Homepage disponível em: https://www.sacoazul.org/.

12 Disponível em: http://maismenos.net/portugal.php.

13 Disponível em: http://maismenos.net/portugal/cap-i.php. 
Miguel Januário subverteu o hino. Deu-lhe um cunho próprio e explicativo da situação atual. Vejamos: em vez da primeira estrofe "Heróis do mar nobre povo", arranca com a frase "Ireis pagar pobre povo". As estrofes vão surgindo escritas em paredes num contexto de desolação e abandono. Trata-se de um espaço industrial abandonado, o que serve como metáfora para o país. Mas continuemos com este hino underground:

Nação doente e mortal/ Leiloai hoje de novo/ o ex-valor de Plutogal/ Entre as lacunas da memória/ ó Pátria sente-se atroz/ o sortilégio posto a vós/que há-de reduzir-te à história/ às lamas/ às lamas/ se sobrar terra e se sobrar mar/ às lamas/às lamas/ se a pátria restar/ contra os barões lutar, lutar.

Neste novo hino ninguém escapa. Os portugueses não escapam e são criticados pela suas lacunas de memória que permitem que tudo isto continue e se repita de quatro em quatro anos. A sobrevalorização da economia, elevada a suprassumo de toda a prática política. A venda ao desbarato de Portugal, que remete para o quadro intensivo de privatizações que esse período de crise experienciou. Mas no fundo existe um vislumbre de esperança. Com todos estes insultos, a pátria "sente-se atroz" e, por isso, na última estrofe Miguel Januário escreve "contra os barões lutar, lutar". Se no contexto do final do século XIX, Henrique Lopes de Mendonça ${ }^{14}$ escreveu "contra os bretões marchar, marchar", hoje são os barões os principais inimigos de Portugal. O inimigo encontra-se cá dentro. O importante a realçar é o facto de que, apesar de toda a crítica, ainda se vislumbra um raio de esperança. É um aviso. E como todos os avisos, existe um conselho, plasmado na estrofe "contra os barões marchar".

A segunda intervenção tem o nome de Traição. ${ }^{15} \mathrm{~A}$ história desta intervenção tem o que se diga. Miguel Januário pretendia colocar uma espada nas costas de D. Afonso Henriques. Após quase um mês a tentar obter autorização, sem obter resposta, da organização do Guimarães Capital da Cultura fazendo-se passar por produtor de cinema, Miguel Januário optou por uma estratégia que lhe é muito cara: escondeu-se à vista de toda a gente e fez o que tinha de fazer (Januário, 2015).

14 Militar e romancista português de finais do século XIX e início do século XX. Ficou mais conhecido por ter escrito a letra do hino português, A Portuguesa, enquanto Alfredo Keil o compôs.

Disponível em: http://maismenos.net/portugal/cap-ii.php. 


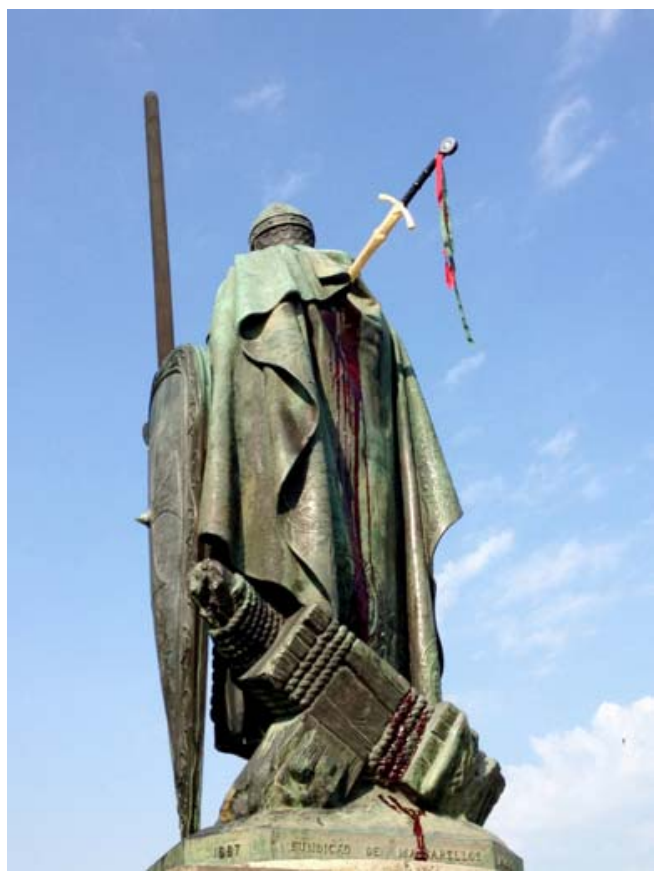

Figura 5. Intervenção Traição, inserida no projeto \pm PORTUGAL 1143-2012 \pm (imagem cedida por Miguel Januário)

O vídeo começa com o famoso Réquiem em ré menor de Mozart. Tendo em conta que se trata de uma missa fúnebre, sabemos que algo de errado aconteceu. Essa sensação só se reforça com o sangue a escorrer a jorros nas imagens a seguir e pessoas a cair na rua. Mas nada nos prepara para a imagem da famosa estátua de D. Afonso Henriques com uma espada nas costas a sangrar. À traição. A última imagem tem lá tudo: a imagem do escudo de Portugal a escorrer sangue. O vídeo é muito claro. Alguém traiu o primeiro rei de Portugal e, por conseguinte, alguém traiu Portugal. A resposta é dura: foram os portugueses. Como Miguel Januário afirma:

Queria representar o facto de Portugal estar a ser traído e pelos próprios portugueses. Daí a faca ter as cores da bandeira nacional. Foi na altura que Portugal abriu as portas à Troika e esta performance é uma metáfora simples. Afonso Henriques é o fundador de Portugal e o país que ele fundou está a deixar de existir 
porque o trabalho que ele começou está a ser vendido e está a perder a independência. Estamos a perder a soberania ao nos entregarmos aos interesses financeiros internacionais. Acaba por simbolizar o país a sangrar. (cf. Garcia, [2015]).

Obtemos a resposta na terceira intervenção, Repressão ${ }^{16}$ Começa com uma das frases mais emblemática do 25 de Abril: "O povo unido jamais será vencido!" Uma frase que nos leva para os dias do PREC, a manifestações do $1^{\circ}$ de Maio, enfim, a momentos de luta social. Mesmo hoje é utilizada recorrentemente em manifestações, de cunho partidário ou não. O problema é que, após esta frase, Miguel Januário justapõe um rebanho de ovelhas a ser pastado por três polícias. Tudo ao som da música de Luís Cília 0 povo unido jamais será vencido. A certa altura, as ovelhas tentam escapar, o que leva à repressão dos polícias que as pastam: depois de uma perseguição, as ovelhas são atiradas para dentro de uma carrinha sob um coro de assobios e de gritos: "Fascistas! Fascistas!" Com um humor negro muito peculiar, Miguel Januário subverte um dos principais símbolos do 25 de Abril (um outro não escapará na performance seguinte). A razão é clara. Os valores do 25 de Abril estão a desaparecer, se não mesmo mortos. $O$ povo são ovelhas pastadas para onde se lhe manda. Mas, novamente, existe um vislumbre de esperança. Parece ser uma das características da obra de Miguel Januário. No pior da situação, existe sempre um caminho. Neste caso encontra-se simbolizado pela tentativa de fuga (falhada) das ovelhas. A ideia é clara: ainda existe alguma força nas ovelhas (isto é, nos portugueses) para tentarem escapar aos seus pastores.

Por fim, chegamos à quarta intervenção, Morte. ${ }^{17}$ É o funeral de Portugal. $\mathrm{O}$ vídeo começa com música gregoriana e duas senhoras de negro a chorar à frente da estátua de D. Afonso Henriques. Estamos num funeral. Quando as senhoras se afastam, vemos um caixão. Um caixão com a forma de Portugal. Em cima do caixão estão cravos vermelhos, um outro símbolo do 25 de Abril, o que simbolizaria novamente a morte dos valores do 25 de Abril. Em seguida começa a marcha fúnebre pelas ruas de Guimarães. Uma marcha com a Guarda Nacional Republicana (GNR) a fazer a guarda de honra. No fim do trajeto, e com várias mulheres a carpir, os sete elementos da GNR carregam as armas e dispararam as salvas.

16 Disponível em: http://maismenos.net/portugal/cap-iii.php.

17 Disponível em: http://maismenos.net/portugal/cap-iv.php. 
A população interagia com a marcha fúnebre, uns a elogiar e outros a dizer que aquilo era uma vergonha. No fundo, o mais e o menos. Os figurantes lamentavam-se e diziam que Portugal era um bom homem, muito bonito, mas tinha um grave defeito: era demasiado generoso, gastava mais do que tinha e dava tudo o que tinha (Pinetree, 2017; Portugal..., 2012). Foi a performance que teve mais repercussão mediática. Nos dias anteriores Miguel Januário fez uma convocatória pelas redes sociais para que todos os portugueses fossem assistir ao enterro de Portugal. Não foram os dez milhões, claro, mas ainda foi um número considerável aquele que acompanhou o cortejo fúnebre.

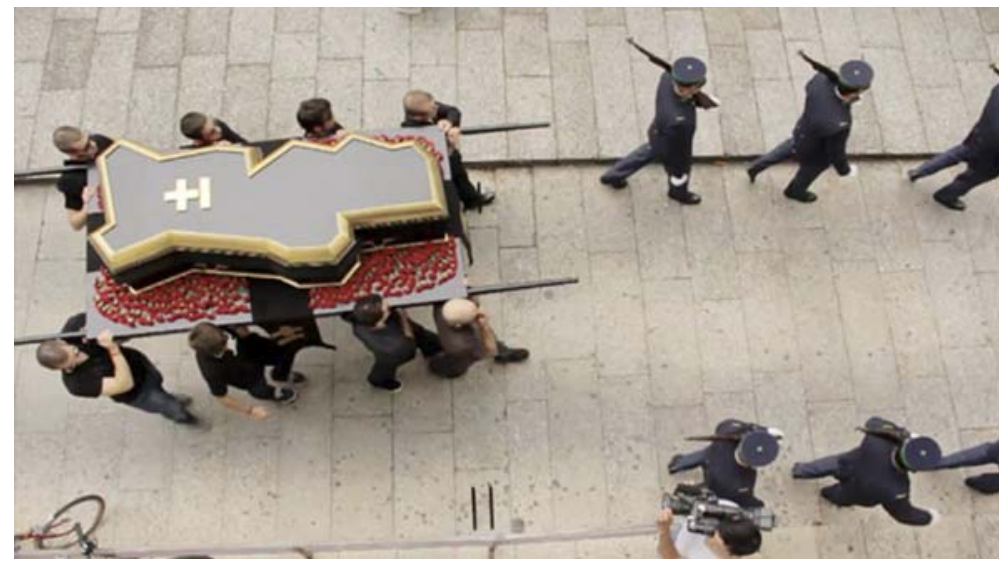

Figura 6. Intervenção Morte, inserida no projeto \pm PORTUGAL 1143-2012 \pm (imagem cedida por Miguel Januário).

Interessantemente, o seu maior momento de fama apenas aconteceu 15 dias depois. A razão foi a seguinte: Miguel Januário contratou várias pessoas para fazer a performance e lembrou-se de contratar a GNR. Assim foi e pagou 280 euros para ter o acompanhamento de sete membros da GNR. No dia, nada aconteceu. O problema foi a reação posterior à participação da GNR. Muitos viram nesta performance não uma metáfora ao estado do país, mas sim algo ofensivo aos símbolos nacionais. Isso e um bode expiatório para certas lutas internas na GNR. Um comandante distrital de Braga acabou por ser 
exonerado. Ironicamente tudo isto serviu para mediatizar ainda mais o projeto (Januário, 2014, 2015). Apesar de ser um projeto paralelo, a organização do Guimarães Capital da Cultura sempre o viu com bons olhos. Acabou mesmo por se tornar algo simbólico para o Guimarães Capital da Cultura (Pinetree, 2017). O que é peculiar. Algo subversivo e crítico mas que acaba por ser apropriado. Algo que por muito que se lute contra isso, nem sempre se consegue controlar. Posto isto, após ter "assassinado" D. Afonso Henriques, Miguel Januário, numa entrevista, questionava-se: "Não percebo o que se passa neste país: já fui jogar golfe para a frente da Assembleia da República, já adulterei o hino e esfaqueei o Afonso Henriques. Não sei o que posso fazer mais" (cf. Henriques, 2012). A resposta foi surpreendente, talvez até para o próprio: está a criar um partido político.

\section{O princípio do fim}

Qual a razão para um partido? Esta ideia surge pela necessidade de repensar $\mathrm{o} \pm$ MaisMenos \pm passados 13 anos de projeto. Um imperativo para reflexionar a domesticação e institucionalização que todos os projetos de intervenção sofrem com o passar do tempo. Se no início escrevia as frases escondido, hoje é convidado. Existe uma canonização que, queria-se ou não, esbate o subversivo de todos os projetos. Ao mesmo tempo, mantinha a ideia que a arte e o design são instrumentos de mudança política. Neste choque, a sua decisão foi tentar falar por cima do sistema (Pinetreee, 2017). Se o projeto estava a ser institucionalizado, a opção era institucionalizá-lo ainda mais: fazendo um partido político. ${ }^{18} \mathrm{Um}$ partido que pretende representar e ter uma postura que não se encontre nos restantes partidos políticos. A capacidade de criar diálogos com o seu mais ou menos, com a sua ambiguidade que permite alargar o seu alcance. No fundo, almeja ser uma plataforma política que reúna em si os contrastes da sociedade. Uma plataforma de consensos (Miguel..., 2018).

Chegando aqui, o que podemos dizer do projeto \pm MaisMenos \pm e de Miguel Januário? Apesar de todas as críticas a Portugal e aos portugueses, mesmo

18 Ainda se encontram no processo de recolha 7500 assinaturas necessárias para se criar um partido político. 
enterrando o país, o seu objetivo não é criticar por criticar. É criticar o estado das coisas. A desmobilização política e a apatia que daí advém. Criticar o político e a sua promiscuidade com o económico. Mas sempre acreditando que um futuro diferente é possível. Se tal não fosse, as duas performances não realizadas do projeto \pm PORTUGAL 1143-2012 \pm não se apelidariam de Ressurreição e Reconquista. E apesar de ironicamente afirmar que "[...] Portugal ainda não está pronto para ressuscitar, por isso decidi parar e esperar pela altura indicada [...]. O corpo ainda está em câmara ardente" (cf. Mais..., 2013), a verdade é que quando olhamos para os títulos que deu a cada apresentação no trabalho artístico \pm PORTUGAL 1143-2012 \pm , não podemos deixar de pensar na Mensagem de Fernando Pessoa, que depois da "noite" e da "tormenta" nos diz: "É a hora!"

Recuperando a nossa proposta de renovação epistemológica, consideramos que o trajeto artístico de Miguel Januário nos permite uma análise mais fina da relação entre arte e crise e, também, de arte e sociedade. Isto pode ser sistematizado em três argumentos. O discurso político e a crítica social levada a cabo pela imaginação artística e expressa numa linguagem artística, se é efetiva em qualquer contexto, é mais pertinente em temos de crise sistémica. Devemos levar isso em consideração aquando uma análise sobre os efeitos da crise económica. Mas não é a única forma que a crise é experienciada e representada em termos simbólicos e estéticos, já que também se torna uma espécie de background que influencia os termos atrás mencionados. Por fim e não menos importante, não é possível alcançar um conhecimento compreensivo sem reconhecer a natureza autónoma da arte face a sociedade e da relação dialógica gerada entre arte e sociedade (Silva; Guerra, 2015; Silva; Guerra; Santos, 2018).

Nestes três níveis, tudo é oblíquo. E esta é a contenda central. Não existem linhas diretas, ligações óbvias, entre a arte e o seu contexto social. É necessário recusar explicações dialéticas e monistas se quisermos capturar a complexidade inerente ao papel das artes. Um tem de lidar com ambiguidade, polissemia e obliquidade. Todavia, obliquidade não implica uma desresponsabilização. Apenas temos de gizar uma abordagem apropriada a esta complexidade (Silva; Guerra, 2015; Silva; Guerra; Santos, 2018). Este artigo foi uma tentativa para o fazer. 


\section{Referências}

ALADRO-VICO, E.; JIVKOVA-SEMOVA, D.; BAILEY, O. Artivism: a new educative language for transformative social action. Comunicar, v. 26, n. 57, p. 9-18, 2018.

ARANTES, O. Urbanismo em fim de linha e outros estudos sobre o colapso da modernização arquitetônica. São Paulo: Edusp, 2000.

ARDENNE, P. Un arte contextual. Murcia: CENDEAC, 2008.

BECKER, H. S. Telling about society. Chicago: The University of Chicago Press, 2007.

BOTTERILL, J. Cowboys, outlaws and artists: the rhetoric of authenticity and contemporary jeans and sneaker advertisements. Journal of Consumer Culture, v. 7, n. 1, p. 105-125, 2007.

BRIGHENTI, A. M. Visibility in social theory and social research. London: Palgrave, 2010.

CAMPOS, R. Entre as luzes e as sombras da cidade: visibilidade e invisibilidade no graffiti. Etnográfica, v. 13, n. 1, p. 145-170, 2009.

CAMPOS, R. Porque pintamos a cidade?: uma abordagem etnográfica do graffiti urbano. Lisboa: Fim de Século, 2010.

CAMPOS, R. A cultura visual e o olhar antropológico. Visualidades, v. 10, n. 1, p. 17-37, 2012a.

CAMPOS, R. A pixelização dos muros: graffiti urbano, tecnologias digitais e cultura visual contemporânea. Revista Famecos, v. 19, n. 2, p. 543-566, 2012b.

CAMPOS, R. O contexto da arte urbana emergente. Seara Nova, n. 1741, 2017. Disponível em: http://www.searanova.publ.pt/pt/1741/cultura/762/O-contexto-da-arte-urbana-emergente.htm. Acesso em: 30 out. 2018.

CANEVACCI, M. A cidade polifônica: ensaio sobre a antropologia da comunicação urbana. São Paulo: Studio Nobel, 1993.

CEREJO, S. D. Risco e identidade de género no universo do graffiti. Lisboa: Colibri, 2007.

CERTEAU, M. de. A invenção do cotidiano. Petrópolis: Vozes, 1994.

COSTA, P.; LOPES, R. Is street art institutionalizable? Challenges to an alternative urban policy in Lisbon. Métropoles, n. 17, 2015a. Disponível em: https://journals.openedition.org/metropoles/5157. Acesso em: 30 out. 2018.

COSTA, P.; LOPES, R. Urban design, public space and the dynamics of creative milieux: a photographic approach to Bairro Alto (Lisbon), Gràcia (Barcelona) and Vila Madalena (São Paulo). Journal of Urban Design, v. 20, n. 1, p. 28-51, 2015b. 
COSTA, P.; LOPES, R. Artistic urban interventions, informality and public sphere: Research insights from three ephemeral urban appropriations on a cultural district. Portuguese Journal of Social Science, v. 16, n. 3, p. 323-342, 2017.

DIÓGENES, G. Artes e intervenções urbanas entre esferas materiais e digitais: tensões legal-ilegal. Análise Social, n. 217, p. 682-707, 2015.

DIÓGENES, G. Arte, pixo e política: dissenso, dissemelhança e desentendimento. Vazantes, v. 1, n. 2, p. 115-134, 2017.

ECKERT, C. A cidade "com qualidade". Estudo de memória e esquecimento sobre medo e crise na cidade de Porto Alegre. Sociedade e Cultura, v. 10, n. 1, p. 61-79, 2007.

ECO, U. Obra aberta. Algés: Difel, 2009.

EUGÉNIO, S. Street art no século XXI: a relação com o mercado da arte. 2013. Dissertação (Mestrado em Gestão Cultural) - Instituto Universitário de Lisboa, Lisboa, 2013.

FELONNEAU, M.-L.; BUSQUETS, S. Tags et grafs: les jeunes à la conquête de la ville. Paris: L'Harmattan, 2001.

FERRELL, J. Crimes of style: urban graffiti and the politics of criminality. Boston: Northeastern, 1996.

FOUCAULT, M. Vigiar e punir: nascimento da prisão. Lisboa: Edições 70, 2013.

FRADIQUE, T. Fixar o movimento: representações da música rap em Portugal. Lisboa: Dom Quixote, 2003.

GARCIA, E. Miguel Januário \pm MaisMenos \pm = Zero. Umbigo Magazine, [2015]. Disponível em: http://umbigomagazine.com/um/2015-08-07/miguel-januario-\%C2\%B1maismenos\%C2\%B1-zero.html. Acesso em: 30 out. 2018.

GARÍ, J. Talking walls: a semiotic approach to graffiti. València: Universitat de València, 1995.

GASTMAN, R.; NEELON, C. The history of American graffiti. New York: Harper Design, 2011.

GOLDSTEIN, J.; PERROTA, A. Let's move, let's tag: ou la rage du spray. Genève: Éditions ies, Haute école de travail social, 1992.

GONÇALVES, F. do N. Arte, ativismo e tecnologias de comunicação nas práticas políticas contemporâneas. Contemporânea, v. 10, n. 2, p. 178-193, 2012.

GUERRA, P. Raw power: punk, DIY and underground cultures as spaces of resistance in contemporary Portugal. Cultural Sociology, v. 12, n. 2, p. 241-259, 2018.

GUERRA, P.; JANUÁRIO, S. Um espelho é mais do que um espelho. Revista NAVA, v. 1, n. 2, p. 202-239, 2016. 
GUERRA, P.; SILVA, A. S. Music and more than music: the approach to difference and identity in the Portuguese punk. European Journal of Cultural Studies, v. 18, n. 2 , p. 201-223, 2014.

HEBDIGE, D. Subculture: the meaning of style. London: Routledge, 1979.

HEIN, H. Public art: thinking museums differently. Lanham: Altamira Press, 2006.

HENRIQUES, A. M. MAISMENOS esfaqueou o rei porque alguém traiu o país. P3, 1 ago. 2012. Disponível em: https://www.publico.pt/2012/08/01/p3/noticia/maismenos-esfaqueou-o-rei-porque-alguem-traiu-o-pais-1814142. Acesso em: 30 out. 2018.

JANUÁRIO, M. The main thing is to act: Miguel Januário: TEDxOPorto. 2014. Disponível em: https://www.youtube.com/watch?v=8iWtTBR4kYo. Acesso em: 30 out. 2018.

JANUÁRIO, M. MaisMenos - ego: Miguel Januário: TEDxLuanda. 2015. Disponível em: https://www.youtube.com/watch?v=K3RO7tCxhQ0. Acesso em: 30 out. 2018.

JENKS, C. The centrality of the eye in western culture: an introduction. In: JENKS, C. (ed.). Visual culture. London: Routledge, 1995. p. 1-15.

KELLENBERGER, S. Espaces publics et formes de mobilisation politique: le rôle des pratiques artistiques. Paris: Programme interministériel de recherches, 2000.

LÉGER, M. J. Brave new avant garde: essays on contemporary art and politics. Washington: Zero Books, 2012.

MAFFESOLI, M. Notas sobre a pós-modernidade: o lugar faz o elo. Rio de Janeiro: Atlântica, 2004.

MAFFESOLI, M. O ritmo da vida: variações sobre o imaginário pós-moderno. Rio de Janeiro: Record, 2007.

MAIS Menos. A exposição onde tudo se vende. Até nada. Jornal i, 12 set. 2013. Disponível em: https://ionline.sapo.pt/303131. Acesso em: 30 out. 2018.

MARINHO, J.; CRUZ, L. Arte urbana: entrevista a Miguel Januário. [s.d.]. Disponível em: https://sites.google.com/site/portefoliojoanamarinho/arte-urbana-entrevista-a-miguel-januario. Acesso em: 30 out. 2018.

MARQUES, S. Miguel Januário. Jornal de Negócios, Lisboa, 17 jun. 2011.

MATOS, R. A relação do writer e do street artist com as galerias de arte: análise do perfil do writer e do street artist português. 2015. Dissertação (Mestrado em Comunicação, Cultura e Tecnologias de Informação) - Instituto Universitário de Lisboa, Lisboa, 2015.

MERRILL, S. Keeping it real? Subcultural graffiti, street art, heritage and authenticity, International. Journal of Heritage Studies, v. 21, n. 4, p. 369-389, 2015. 
MIGUEL Januário quer fazer do \pm MaisMenos \pm um partido político e está a recolher assinaturas. Shifter, 22 set. 2018. Disponível em: https://shifter.sapo.pt/2018/09/ miguel-januario-maismenos-partido-politico/. Acesso em: 30 out. 2018.

MOORE, M.; CRUZ, L. VSP - Visual Street Performance. Lisboa: Pintas em Fúria, 2008.

MOURÃO, R. Representações de contrapoder: performances artivistas no espaço público português. 2013. Dissertação (Mestrado em Antropologia) - Instituto Universitário de Lisboa, Lisboa, 2013.

MOURÃO, R. Performances artivistas: incorporação duma estética de dissensão numa ética de resistência. Cadernos de Arte e Antropologia, v. 4, n. 2, p. 53-69, 2015.

PAIS, J. M. Lufa-lufa quotidiana: ensaios sobre cidade, cultura e vida urbana. Lisboa: Imprensa de Ciências Sociais, 2010.

PAULOS, P. Coruja VS Coruja. A arte urbana a enfrentar a publicidade, ou o marketing a reinventar-se?. Vice, 15 mar. 2018. Disponível em: https://www.vice.com/pt/ article/437kdj/coruja-vs-coruja-a-arte-urbana-a-enfrentar-a-publicidade-ou-o-marketing-a-reinventar-se. Acesso em: 30 out. 2018.

PINETREE, J. No carro com Miguel Januário ( \pm MAISMENOS \pm ). 2017. Disponível em: https://www.youtube.com/watch?v=iQHMH27DkqI. Acesso em: 30 out. 2018.

PORTUGAL "morto à traição" foi a enterrar em Guimarães. TVI24, 28 ago. 2012. Disponível em: https://tvi24.iol.pt/sociedade/iol-push/portugal-morto-a-traicao-foi-a-enterrar-em-guimaraes. Acesso em: 30 out. 2018.

RAMALHO, R. L. Miguel Januário. PARQ, ano 6, n. 44, p. 34-39, 2014. Disponível em: https://issuu.com/parqmagazine/docs/parq44. Acesso em: 30 out. 2018.

RAPOSO, P. "Artivismo": articulando dissidências, criando insurgências. Cadernos de Arte e Antropologia, v. 4, n. 2, p. 3-12, 2015.

SCOTT, A. J. Beyond the creative city: cognitive-cultural capitalism and the new urbanism. Regional Studies, v. 48, n. 4, p. 565-578, 2014.

SEQUEIRA, A. D. A cidade é o habitat da arte: street art e a construção de espaço público em Lisboa. 2015. Tese (Doutorado em Sociologia) - Instituto Universitário de Lisboa, Lisboa, 2015.

SILVA, A. S. A democracia portuguesa face ao património cultural. Revista da Faculdade de Letras: Ciências e Técnicas do Património, v. 13, p. 11-32, 2014.

SILVA, A. S.; GUERRA, P. As palavras do punk. Lisboa: Alêtheia, 2015.

SILVA, A. S.; GUERRA, P.; SANTOS, H. When art meets crisis. The Portuguese story and beyond. Sociologia, Problemas e Práticas, n. 86, p. 27-43, 2018. 
SILVA, H. T. da. Contra o carrossel do entretenimento. Jornal de Notícias, Porto, p. 35, 28 jun. 2005.

SNYDER, G. J. Graffiti lives: beyond the tag in New York's urban underground. New York: NYU Press, 2011.

STAHL, J. Street art. Königswinter: Tandem Verlag, 2009.

TRAQUINO, M. A construção do lugar pela arte contemporânea. Vila Nova de Famalicão: Húmus, 2010.

TRAQUINO, M. As sementes foram plantadas à mão. Cidades, Comunidades e Territórios, n. 34 p. 17-29, 2017.

WACLAWEK, A. From graffiti to the street art movement: negotiating art worlds, urban spaces, and visual culture, c. 1970-2008. 2008. Tese (Doutorado em História da Arte) - Faculty of Fine Arts, Concordia University, Montreal, 2008.

WACLAWEK, A. Graffiti and street art. London: Thames \& Hudson, 2011.

Recebido: 30/10/2018 Aceito: 15/04/2019 | Received: 10/30/2018 Accepted: 4/15/2019 